\title{
AN EVALUATION OF BS-VI FUEL EMISSION STANDARDS IN INDIA
}

\section{DR CHIVKULA ANIRVINNA ${ }^{1} \&$ DR SMITA SHARMA ${ }^{2}$}

\author{
${ }^{1}$ Associate Professor, TAPMI School of Business, Manipal University Jaipur, Jaipur, Rajasthan, India \\ ${ }^{2}$ Assistant Professor, TAPMI School of Business, Manipal University Jaipur, Jaipur, Rajasthan, India
}

\section{ABSTRACT}

The United Nations Climate Change Conference, held in Paris in 2015, had set the right tone for a climate policy for all the nations to embark on ambitious efforts to combat climate change. It encouraged all the nations to adapt technologies and strategies that promote sustainable global climate efforts and keep temperature below $2^{\circ} \mathrm{C}$ from pre-industrial times. India too has made an admirable national effort to keep pace with Paris Convention target by introducing Bharat Stage VI fuels in New Delhi from April 12018 and NCR by April 2019 amid public outcry about poor air quality in the national capital. The poor air quality could be blamed on vehicular emissions of ill-maintained commercial vehicles with old engines crowding the city. India as per the international practices introduced higher fuel grade a couple years before the new emission standards kick in. The recent Supreme Court order to ban the sale and registration of the current Bharat Stage-IV vehicles by automobile industry from $1^{\text {st }}$ April 2020 speaks volumes about the seriousness of the government's intention to improve the air quality in India. This article critically evaluates the government's decision vis-à-vis other stakeholders. It also lays down policy prescriptions and outlines future questions which can be derived by from this study.

KEYWORDS: Bharat Stage Emission Norms, BS-VI Fuel Policy, Vehicle Exhaust Emissions, Automobile Manufacturers, Oil Marketing Companies, Air Pollution, Electric Vehicle

Received: Aug 26, 2020; Accepted: Sep 16, 2020; Published: Nov 06, 2020; Paper Id.: IJMPERDOCT202027

\section{INTRODUCTION}

Thanks to liberalization in the 1990s the economy witnessed spurt in overall growth in general and industrial sector. This trend has been sustained as a result of moves on liberalization fueling growth. The impressive growth of the economy has taken a toll on the human beings with ever increasing vehicular emissions in the country. The pollutants have been shown to be detrimental to human health and to the natural environment. While air pollution alone cannot squarely be blamed on vehicular emissions, the lion's share of the blame has to be borne by failure to rein in vehicle emissions in the country. The World Health Organization Chief Tedros Adhanom Ghebreyesus has rightly commented that air pollution is the new tobacco. With as many as 20 most polluted cities in the world located in India in terms of Particulate Matter (PM) 2.5 levels, it becomes a serious matter that is gaining urgency. It is surely a bad sign for a fast-developing economy like that of India. What is worrisome is that 14 cities are concentrated in a belt that extends from Punjab to Bihar. Between 2007 and 2017 the air quality has gone from bad to worse. New Delhi is the worst affected among the cities in India in respect of toxic quality of air. Crop burning during the winter accounts for 26\% of PM 2.5 pollution. The crop stubble burning ban enforced by National Green Tribunal (NGT) on Haryana, Punjab, Rajasthan and Uttar Pradesh could not achieve the satisfactory results. The air pollution in Delhi has been rightly described as health emergency. The Finance Minister in the Union Budget 2020 has enhanced outlay by almost tenfold by Rs4.400 crores for controlling air pollution. The states too need to 
follow the similar practices. The Delhi government introduced the odd even policy in 2016 as a way of reducing pollution from exhaust gases released by vehicles. The National Clean Air Programme has set an ambitious goal of improving air quality by 25 to $30 \%$. Since the causes of air pollution and mitigation measures are better appreciated now, it is high time we set a new target for the nation to get fully clean air by 2025. India has been generating economic losses of 8 billion a day, according to Greenpeace Report. India has been bearing an economic cost running into $\$ 150$ billion annually because of air pollution.

The article critically evaluates and analyses the decision of the Union Government of India to skip the BS-V emission norms and progress directly to BS-VI norms. It also studies how it impacts the various stakeholders such as the automobile manufactures, oil marketing companies and customers. Finally, the article also focuses on how it will help the government in containing air pollution levels. The data collected for the study is from various secondary sources of published business news and websites. The collected data is tabulated, and meaningful analysis is applied to arrive at logical conclusions.

\section{LITERATURE REVIEW}

Green diesel has been gaining popularity due to it cetane index-diesel and caloric value than that of petrol -diesel, biodiesel and hybrid fuel. The study investigates the production of green diesel from waste cooking oil by hydroprocessing and TBP distillation (Deepak Singh, et al 2019) Across the globe road transportation has attracted a wide attention especially in a country like China where road traffic had outgrown that of other countries. Hence there is a dire need of appropriate fuel pricing policy which can reduce the overconsumption of fuel. Their study has found not only direct correlation between pricing and the demand for gasoline but also potential demand reductions and Green Gas House emissions. This is due to strategic tax implementation in China which was examined up to 2030 (Wang Yuto, et al 2013) Petrol and diesel are being extensively demanded for running internal combustion (IC) engines. As the demand for automobiles increases with the growing urbanization and development, more and more petroleum products are consumed resulting in depletion of resources. Hence it is high time we found an alternative fuel to run the same IC. Since alternative fuel is less inefficient in comparison with the conventional petroleum products there is a great need to improve the efficiency of IC engine. Bio- origin fuels have been found to be an alternative to petroleum products as they can meet not only the growing demand for automobile sector but also help in pollution control and protection of environment.(Patel Harish Kumar \& Kumar Saurabh, 2017) P-Series fuels require no special fuel management as they can be easily intermixed with gasoline. It is an inexpensive fuel generated by municipal and agricultural waste hence helps in reducing petroleum use as compared to gasoline. $\mathrm{P}$ fuels are as economically competitive as gasoline and significantly reduce the toxic emissions. (Yakap Kaur\& Huseyin Devic, 2007) Manufacturers and energy companies are working rigorously to innovate cars which would produce zero emissions may be as a result of being powered by hydrogen which produces harmless water from exhaust. Soon we can have the perfect world that is free from pollution and vehicular emissions (Martin Derrick, 2003). Customer preferences were sensitive to changes in fuel efficiency and emission levels. However, engine power was the most crucial factor for existing owners, whereas price was the most important one for potential customers, while both market segments valued emission more than fuel efficiency. Also, the domestic producer will benefit from both an increase in market size and market share if all new vehicles have higher fuel efficiency but this producer's market share will decrease if all new vehicles have lower CO2 emissions.(Chowdhary Mahzabin, et al 2016) There are studies on green diesel, taxation of fuel to reduce consumption and Green Gas House emissions, alternative fuel to run IC, Innovative cars 
and customer preferences for fuel efficient cars etc. But there have hardly been any studies on evaluation of BS-VI fuel standard norms in India

Automobiles emit exhaust gases that consist of both harmful and non-harmful gases. A major portion of these gases consists of non-harmful gases such as nitrogen (N2), water vapor $(\mathrm{H} 2 \mathrm{O})$ and carbon dioxide (CO2). Harmful gases are also referred to as pollutants. carbon monoxide (CO) due to incomplete combustion, nitrogen oxides (NOx) generated at high temperature, hydrocarbons (HC) obtained from unburnt fuel, particulate matter (PM, mostly soot) and oxides of sulphur (SOx) due to sulphur presence in the fuel, are some of the pollutants. There are over 700,000 trucks, buses and taxis manufactured before 31 December 2000 that contribute to $15-20 \%$ of vehicular pollution, according to a study by AT Kearney based on data from Central Pollution Control Board and Union road ministry's emission norms

This decision to leapfrog from BS-VI to BS-IV norms has managed to disrupt oil and automotive industry. For diesel engines a diesel particulate filter for moving to BS V and Selective Catalytic Reduction for BS-VI is necessary. For Spark-ignition engine (S.I engine) the new technologies that are likely to be commercialized will help vehicles to comply with BS-VI norms.

The automobile sector faces problems such as upgradation of technology, validation of technology and making the technology acceptable to the customers. Oil refineries too face some challenges. These include reduced timeline, choosing appropriate technology for refining, redesigning the existing unit and simultaneous distribution of two types of oil. Investments worth Rs. 1.5 lakh crore by the automotive industry and Rs 80,000 crore by oil refineries have to be made for upgradation to BS-VI norms by 2020 in India.

India first embarked on emission norms for petrol vehicles in 1991 and for diesel vehicles in 1992. Emission norms were further tightened in 1995 with the compulsory fitment of catalytic converters in petrol vehicles sold in the four major cities along with the supply of unleaded petrol (ULP). Availability of ULP was extended to 42 major cities and now it is available across the country. Since harmful gases in the exhaust system pollute the atmosphere the catalytic converters are fitted into the modern car exhaust pipes to make the exhaust fumes safer. Bharat Stage emission norms (Table I), which are equivalent to Euro norms for four-wheeled vehicles, were first introduced in the year 2000. These norms specify the maximum permissible emission limit for major pollutants such as carbon monoxide (CO), hydrocarbons (HC), nitrous oxides (NOx) and particulate matter (PM).

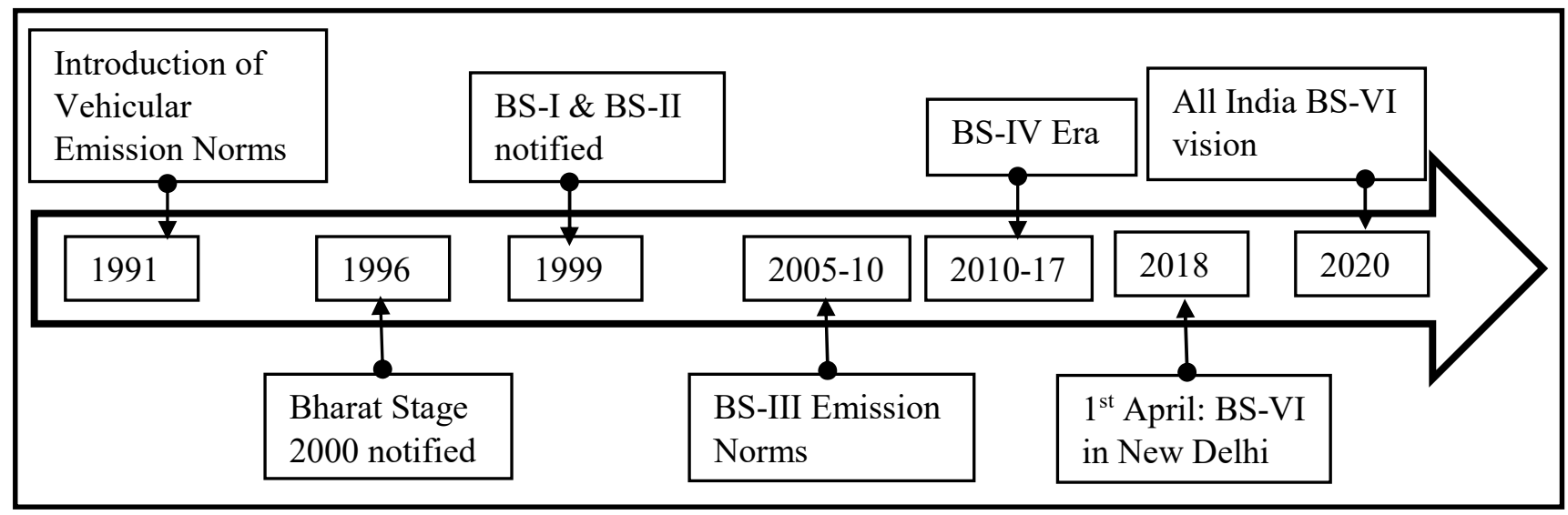

Figure 1: Journey of Bharat Stage Emission Norms and Fuel Improvements Source: The Financial Express, December 15 ${ }^{\text {th }}, 2017$ p.5 
As of 2018, BS-IV norms are applicable in 13 major cities of the country, while BS-III norms are applicable elsewhere. As per an Expert Committee constituted in 2013 to draft updated Automotive Fuel Policy 2025, which was published in May 2014, BS-IV roll-out was envisaged for the entire country by 2017, BS-V by 2021 and BS-VI by 2024. However, on January 6th 2016, the Union Government of India took the decision to skip the BS-V emission norms and progress directly to BS-VI norms by April 2020. The jump from BS-IV to BS-VI created challenges for the Oil and Automotive industries

\section{THE DECISION TO LEAPFROG FROM BS-IV TO BS VI}

The global energy related carbon emissions might have flattened out at 33 gigatons in 2019 due to increase in the usage of renewable sources of energies especially the wind and solar energies, replacing coal with natural gas, nuclear power, milder weather and slower economic growth in emerging markets. But in reality, $70 \%$ of the global energy demand is met by oil, natural gas, and coal, while renewable sources accounted for the remaining 30\%. Carbon dioxide emissions are the primary contributor to the rise in average global temperatures. This problem needs to be addressed to counter the devastating effects of climate change evident from recent trends such as Super Winter in Europe \& North America.

India has the maximum number of polluted cities in the world. India ranked sixth on the list of 98 countries in PM2.5 concentration behind Pakistan and Bangladesh. Delhi has the dubious record of being the most polluted capital city in the world. According to the report of AirVisual, 21 out of 30 most polluted cities in 2019 were present in India. Also, air pollution is the fifth leading cause of mortality in India

Meanwhile, multiple studies have concluded that primary sources of air pollution vary seasonally in winter; it is the practice of crop stubble burning which leads to air pollution whereas in early summer the dust from construction activities is an active pollutant. It is argued that until these sources are not handled suitably, the benefits of controlling vehicular pollution will not be significant. India has been tardy in implementing stricter emission norms thanks to the indifferent attitude shown by regulatory authorities to ever raising vehicular pollution levels and their adverse impact on the environment. Adding to regulatory lethargy, the Indian auto mobile industry has never been proactive and has shown resistance to change due to investment and cost factors. The vehicles in the national capital of Delhi have contributed to an alarming rise of $59 \%, 50 \%$ and $18 \%$ of harmful gases to overall emissions. These harmful gases are carbon monoxide, hydrocarbons and nitrous oxides respectively. There is a growing concern among policy makers and environmental activists in India that auto makers need to bring down carbon footprints by adhering to emission standards

India has traditionally been a laggard in terms of enforcing and implementing emission norms for the manufacturing sector. Indian automotive industry is not an exception to this either. There is a strong opinion emerging among policymakers and environmental groups in India that stricter emission standards need to be implemented for all kinds of vehicles in the country.

The move to directly implement BS-VI norms instead of BS-V norms will reduce nitrogen oxide (NOx) emissions by $25.8 \%$ in petrol engine vehicles and by $68 \%$ in diesel engine vehicles. BS-VI will also ensure the Particulate Matter reduction which earlier was not considered for BS-III and BS-IV. Particulate matter emissions, (Table I) a major component of outdoor air pollution, are expected to get reduced drastically by over $80 \%$ in diesel engine vehicles. 
Table I: Reduction in Nitrous Oxide and Particulate Matter Emissions as per BS-VI Norms

\begin{tabular}{|l|l|l|}
\hline \multicolumn{1}{|c|}{ Reduction in Emissions } & NOX Emissions (g/km) & PM Emissions (g/km) \\
\hline Diesel Vehicles & $68 \% \downarrow$ & $87 \% \downarrow$ \\
\hline Heavy Duty Vehicles & $82 \% \downarrow$ & $67 \% \downarrow$ \\
\hline
\end{tabular}

Source: Live mint, March 31st, 2018, p11

As it can be seen (Table II) BS-VI or Euro 6 emission standards need to be implemented at the earliest because diesel emissions close gap with petrol emissions only at the BS-VI stage to address the hazard risk as per the report of Environment Pollution Prevention and Control Authority (EPCA). BS-VI vehicles have fuel that contains lower levels of sulphur when compared with the fuels used by BSIV vehicles. In diesel Sulphur content gradually reduced from 350 ppm (parts per million) in BS III to $50 \mathrm{ppm}$ in BS-IV and $10 \mathrm{ppm}$ in BS-VI. Similarly, in petrol, the sulphur content gets reduced from $150 \mathrm{ppm}$ to $50 \mathrm{ppm}$ then to $10 \mathrm{ppm}$ gradually.

Table II: Comparison of Emission Standards for Light -Duty Vehicles in BS-IV \& BS-VI Norms

\begin{tabular}{|c|c|c|c|c|c|c|c|}
\hline \multicolumn{8}{|c|}{ Emission Standards for Light-Duty Vehicles } \\
\hline & $\begin{array}{c}\text { BS-IV } \\
\text { Norms } \\
\end{array}$ & & & & $\begin{array}{c}\text { BS-VI } \\
\text { Norms }\end{array}$ & & \\
\hline $\begin{array}{c}\text { Diesel } \\
\text { Vehicle }\end{array}$ & Units & $\begin{array}{c}\text { M\& N1 } \\
\text { Class1 }\end{array}$ & $\begin{array}{c}\text { N1 cLass } \\
\text { II }\end{array}$ & $\begin{array}{c}\text { N1 Class } \\
\text { III }\end{array}$ & $\begin{array}{c}\text { M\& N1 } \\
\text { Class1 }\end{array}$ & $\begin{array}{c}\text { N1 cLass } \\
\text { II }\end{array}$ & $\begin{array}{c}\text { N1 Class } \\
\text { III }\end{array}$ \\
\hline $\mathrm{CO}$ & $\mathrm{g} / \mathrm{km}$ & 0.5 & 0.63 & 0.74 & 0.5 & 0.63 & 0.74 \\
\hline $\mathrm{HC}$ & $\mathrm{g} / \mathrm{km}$ & & & & & & \\
\hline $\mathrm{HC}+\mathrm{Nox}$ & $\mathrm{g} / \mathrm{km}$ & 0.3 & 0.39 & 0.46 & 0.17 & 0.195 & 0.215 \\
\hline Nox & $\mathrm{g} / \mathrm{km}$ & 0.25 & 0.33 & 0.39 & 0.08 & 0.105 & 0.125 \\
\hline PM & $\mathrm{g} / \mathrm{km}$ & 0.025 & 0.04 & 0.06 & 0.0045 & 0.0045 & 0.0045 \\
\hline $\mathrm{PN}$ & $\mathrm{g} / \mathrm{km}$ & & & & $6 \times 1011$ & $6 \times 1011$ & $6 \times 1011$ \\
\hline $\begin{array}{l}\text { Petrol } \\
\text { Vehicle }\end{array}$ & Units & $\begin{array}{c}\text { M\& N1 } \\
\text { Class1 }\end{array}$ & $\begin{array}{l}\text { N1 cLass } \\
\text { II }\end{array}$ & $\begin{array}{l}\text { N1 Class } \\
\text { III }\end{array}$ & $\begin{array}{c}\text { M\& N1 } \\
\text { Class1 }\end{array}$ & $\begin{array}{l}\text { N1 cLass } \\
\text { II }\end{array}$ & $\begin{array}{c}\text { N1 Class } \\
\text { III }\end{array}$ \\
\hline $\mathrm{CO}$ & $\mathrm{g} / \mathrm{km}$ & 1 & 1.81 & 2.27 & 1 & 1.81 & 2.27 \\
\hline $\mathrm{HC}$ & $\mathrm{g} / \mathrm{km}$ & 0.1 & 0.13 & 0.16 & 0.1 & 0.13 & 0.16 \\
\hline $\mathrm{HC}+\mathrm{Nox}$ & $\mathrm{g} / \mathrm{km}$ & & & & & & \\
\hline Nox & $\mathrm{g} / \mathrm{km}$ & 0.08 & 0.1 & 0.11 & 0.06 & 0.075 & 0.082 \\
\hline PM & $\mathrm{g} / \mathrm{km}$ & & & & 0.0045 & 0.0045 & 0.0045 \\
\hline $\mathrm{PN}$ & $\mathrm{g} / \mathrm{km}$ & & & & $6 \times 10$ & $6 \times 10$ & $6 \times 10$ \\
\hline
\end{tabular}

Source: Source: Retrieved ( 21st February,2020) from http//www.cpcb.nic.in

With the implementation of BS-VI norms, the sulphur content in fuel will be reduced to $10 \mathrm{ppm}$, which is equal to the European standards. Globally, fuel sulphur has been found to contribute to sulphur oxide emissions resulting in respiratory diseases and acid rain. Countries such as Japan and Australia have minimized the sulphur content to 10 ppm10 (Table III) and over a prolonged duration, this has resulted in improved air quality. Still, Russia and Malaysia have alarming levels of fuel sulphur content which compromises the air quality and jeopardizes the health of citizens

Table III: Global Comparison of Fuel Sulphur Content (in parts per million

\begin{tabular}{|l|l|l|}
\hline \multicolumn{1}{|c|}{ S. No. } & \multicolumn{1}{|c|}{ Country } & \multicolumn{1}{|c|}{$\begin{array}{c}\text { Fuel Sulphur Emission Norms } \\
\text { (2018) }\end{array}$} \\
\hline 1 & India & BS-VI fuel with 10 ppm sulphur \\
\hline 2 & European Union & $\begin{array}{l}27 \text { EU Nations }- \text { Euro-VI fuel } \\
\text { with } 10 \text { ppm sulphur }\end{array}$ \\
\hline 3 & United States & Diesel $15 \mathrm{ppm} \mathrm{\&} \mathrm{Petrol} 80 \mathrm{ppm}$, \\
\hline
\end{tabular}




\begin{tabular}{|l|l|l|}
\hline & & $\begin{array}{l}\text { California has ultra-low Sulphur } \\
\text { fuel }\end{array}$ \\
\hline 4 & Japan & Petrol \& Diesel with 10 ppm \\
\hline 5 & Australia & Gasoline \& Diesel with 10 ppm \\
\hline 6 & China & $\begin{array}{l}\text { Euro IV in Beijing \& Shanghai, } \\
\text { Euro III All-China }\end{array}$ \\
\hline 7 & Russia & $\begin{array}{l}\text { Diesel 350 ppm \& Petrol 150 } \\
\text { ppm }\end{array}$ \\
\hline 8 & Malaysia & Petrol \& Diesel with 500 ppm \\
\hline
\end{tabular}

Source: The Indian Express, March 10th, 2018, p8

\section{TECHNOLOGICAL IMPROVEMENTS AND COST IMPLICATION}

In the case of diesel engines, three devices i.e. catalytic converter, Diesel Particulate Filter (DPF) and Selective Catalytic Reduction (SCR) are required to be installed in series. For petrol engines, conversion from BS-IV to BS-VI engine requires the following modifications: Redesigning of ports and exhaust system improvements, adoption of higher compression ratios along with improved carburetion, combustion chamber redesign, sparkplug re-location and piston redesign.

The two and three wheelers will also have to be fitted with Electronic Fuel Injection system in place of the old Carburetor system, to meet the BS-VI standards.

Table IV: Likely Technologies for vehicles and cost implications

\begin{tabular}{|c|c|c|c|}
\hline \multicolumn{4}{|c|}{ Likely Technologies Across Vehicles Categories and Cost Implications } \\
\hline Segment & Current Technology_(BS-111 or BS-IV) & Technology to meet BS-VI Norms & Cost implications \\
\hline \multirow[t]{2}{*}{$\begin{array}{l}\text { Two } \\
\text { Wheelers }\end{array}$} & Exhaust -Three Way Catalytic Converter & $\begin{array}{l}\text { Combustion-Electronic Fuel } \\
\text { injection(EFI) }\end{array}$ & $\begin{array}{l}\text { Rs. } 5,000 \cdot 6,000 \text { per vehicle } \\
\text { (P) }\end{array}$ \\
\hline & Exhaust -Three Way Catalytic Converter & $\begin{array}{l}\text { Exhaust-Three way Catalytic } \\
\text { Converter }\end{array}$ & $(-10 \%$ of vehicle cost $)$ \\
\hline \multirow[t]{4}{*}{$\begin{array}{l}\text { Three } \\
\text { Wheelers }\end{array}$} & $\begin{array}{l}\text { Combustion -Carburetor (P), Direct } \\
\text { Injection (D) Exhaust-Oxidation Catalytic } \\
\text { Converter (P) }\end{array}$ & $\begin{array}{l}\text { Combustion -Electronic Fuel } \\
\text { Injection (EFI) }\end{array}$ & $\begin{array}{l}\text { Rs. } 5,000-6,000 \text { per vehicle } \\
\text { (D) }\end{array}$ \\
\hline & Exhaust-Oxidation Catalytic Converter & High Pressure Direct Injection & $(-5 \%$ of vehicle cost $)$ \\
\hline & & $\begin{array}{l}\text { Exhaust-Three Way Catalytic } \\
\text { Converter }\end{array}$ & $\begin{array}{l}\text { Rs. 7,000-8,000 per vehicle } \\
\text { (D) }\end{array}$ \\
\hline & & May Require EGR() & $(-5 \%$ of vehicle cost $)$ \\
\hline \multirow[t]{4}{*}{$\begin{array}{l}\text { Passenger } \\
\text { Vehicles- } \\
\text { Petrol } \\
\end{array}$} & Combustion -Multi Point Fuel Injection & $\begin{array}{l}\text { Improved Version of MPFI and Three } \\
\text { Way }\end{array}$ & $\begin{array}{l}\text { Rs. } 20,000-30,000 \text { Per } \\
\text { vehicle }\end{array}$ \\
\hline & Exhaust -Three Way Cata lytic Converter & $\begin{array}{l}\text { Catalytic Converters; Engine } \\
\text { Downsizing }\end{array}$ & $\{-4-6 \%$ of vehicle cost $\}$ \\
\hline & & $\begin{array}{l}\text { Combustion -Gasoline Direct } \\
\text { injection }\end{array}$ & $\begin{array}{l}\text { It may go significantly if } \\
\text { Oem's switch to GOI } \\
\text { Technology }\end{array}$ \\
\hline & & Exhaust-Gasoline particulate Filter & \\
\hline \multirow[t]{3}{*}{$\begin{array}{l}\text { Passenger } \\
\text { Vehicles- } \\
\text { Diesel } \\
\end{array}$} & $\begin{array}{l}\text { Combustion-Common Rail Direct } \\
\text { Injection(CRDI) }\end{array}$ & Main changes in fuel injection system & $\begin{array}{l}\text { Rs-75,000-1,00,000 per } \\
\text { vehicle }\end{array}$ \\
\hline & with Turbocharger and EGR & $\begin{array}{l}\text { Exhaust-LNT for controlling Nox } \\
\text { levels }\end{array}$ & $(10-12 \%$ of vehicle cost $)$ \\
\hline & Exhaust -Diesel Oxidation Catalyst & $\begin{array}{l}\text { Exhaust-DPF for controlling PM } \\
\text { levels }\end{array}$ & \\
\hline Light and & Exhaust -DOC in BS-III & Combustion-High pressure Direct & Engine cost could go up by \\
\hline
\end{tabular}




\begin{tabular}{|l|l|l|l|} 
Medium CVs & & Injection & $\begin{array}{l}50 \% \text { from a base level of } \\
\text { Rs. 200000(For BS-IV) }\end{array}$ \\
\hline & Exhaust -EGR or SCR in BS-IV & Exhaust-DOC for CO and Hc levels & \\
\hline & & Exhaust -EGR+ SCR for Nox levels & \\
\hline Heavy CVs & & Exhaust-DPF for PM levels & $\begin{array}{l}\text { Engine cost could go up by } \\
50 \% \text { from a base level of } \\
\text { Rs. 300000 (For BS-IV) }\end{array}$ \\
\hline & Exhaust -DOC in BSIII & $\begin{array}{l}\text { Combustion-High pressure Direct } \\
\text { Injection }\end{array}$ & \\
\hline & Exhaust -EGR or SCR in BS IV & Exhaust-DOC for CO and HC levels & \\
\hline & & Exhaust -EGR+ SCR for Nox levels & \\
\hline
\end{tabular}

Source: Retrieved (1st March.2020) http//www.cpcb.nic.in

It is evident from the likely technological requirements (Table IV), that the impact of the cost implications will be higher for the diesel passenger vehicles as compared to the petrol vehicles, as percentage of vehicle cost. The cost implications will be lower for the light \& medium weight vehicles and higher for the heavy commercial vehicles corresponding to the increase in the engine displacement leading to an increase in engine cost. Mercedes Benz and BMW the two luxury brands are streets ahead of the country's biggest carmaker, Maruti Suzuki in the introduction of BS-VI compliant vehicles. An estimated increase of INR 100,000 for diesel cars and INR 20,000 for petrol13 cars is expected with the switch to BS-VI. Now Maruti Suzuki has already launched BS-VI compliant version of its best-selling van Eeco.

The technological improvements across all segments will be focused on the Exhaust system \& Fuel Injection system. The main focus will be on reducing the harmful NOX \& hydro carbon emissions that are detrimental to the Ozone layer at the atmospheric level and to life at ground level.

\section{STAKEHOLDERS}

The issue is bound to affect a wide range of stakeholders, both directly and indirectly, but the impact and degree of the effect are yet to be seen. Perhaps, only time will tell how well, those involved can handle the consequences of this transition to BS-VI emission norms.

The primary stakeholders are the central government and state governments, heavily polluted metro cities such as New Delhi, Mumbai and Kolkata; the automobile manufacturers; the automotive ancillary \& OEM firms; Oil Marketing Companies (OMCs) and the vehicle owners who presently drive BS-IV models. All these stakeholders will have to settle for the new fuel optimized for BS-VI standards.

The secondary stakeholders are: the central government agencies such as the Central Pollution Control Board (CPCB), Ministry of Heavy Industries, Ministry of Environment, Forest and Climate Change, Ministry of Petroleum \& Natural Gas, Ministry of Road Transport and Highways, National Green Tribunal (NGT), Oil and Natural Gas Corporation (ONGC), Automotive Research Association of India (ARAI) and the Society of Indian Automobile Manufacturers (SIAM).

\section{CHALLENGES AND ISSUES}

The technological complications and challenges associated with the transition, have led to a variety of issues concerning the stakeholders. The issues related to the beleaguered automotive manufacturers include: an increase in the vehicle 
dimension and corresponding taxation to accommodate emission controlling devices; increased cost for a Particulate Matter Filter and Selective Catalytic Reduction device; time lag and the economic viability - since several Indian car manufacturers source engines from common engine manufacturers like Fiat.

For the oil refineries, a shift to BS-VI fuel will lead to issues such as: transportation of new fuel variant through existing pipelines resulting in contamination; wastage of existing BS-IV fuel inventory; optimum pricing for BS-VI fuel and disruption in supply and distribution across the wide geographical territory.

The decision to shift to BS-VI emission norms has caused an uproar in the domestic passenger vehicle market. The disruption caused by the transition is bound to increase the cost of new vehicles, a consequence that will affect the car buyers' budget.

\section{CONCLUSIONS}

It is clear from our daily experiences on the road that it is the old vehicles, especially trucks and goods carriers, which are often the most polluting vehicles rather than passenger vehicles. Experts opine that the National Green Tribunal must shift its focus to the Vehicle Scrapping Policy of the government instead of focusing only on implementation of BS-VI norms. There are over 35 million trucks, buses and taxis manufactured before 31 December 2000 that contribute to three-fourths of vehicular pollution, according to a study by AT Kearney based on data from Central Pollution Control Board and Union road ministry's emission norms. The Central Government's ambitious vehicle scrapping policy will become compulsory for all commercial vehicles from 2020 onwards and their life will be capped at 20 years. Vehicles manufactured prior to 31 st December 2000 will be deemed obsolete and banned from plying on roads. In addition, the voluntary vehicle fleet modernization program (V-VMP) policy aims at scrapping 15 -year-old commercial vehicles in the first phase. The V-VMP policy proposes to take 28 million decade-old vehicles off the road and once it is implemented, pollution would be checked considerably as $65 \%$ of the pollution is caused by heavy vehicles that are more than 15 years old. The implementation of this policy, though a mammoth task, will go a long way in curbing vehicular emissions and is expected to have a profound impact on lowering air pollution levels.

Nevertheless, vehicle manufacturers are investing in the technology to deliver vehicles according to the BS-VI guidelines, but they are unlikely to release cars before the deadline because new engines mean new costs and higher prices of the vehicles. However, Mercedes-Benz India has introduced the S-Class with BS-VI-compliant made-in-India engines two years prior to the deadline.

India plans to skip BS V and move to BSVI directly. This requires fitting equipment using emission reducing technology such as DPF and SCR in four-wheelers. Though this requires additional investment in time and capital, given the environmental benefits associated with it, it is a step that must be taken by automobile companies. Still shifting directly to BS-VI poses enormous technological challenges to the automobile makers. The BS-VI will help in reducing the emission of harmful contents to the atmosphere from automotive engines and control the air pollution levels. The alternate technologies such as Electric Vehicles and Hybrid vehicles can complement the BS-VI emission norms to reduce vehicular emissions further. The challenges associated with such vehicles range from charging point issues to speed and pick-up. The Nissan Leaf is an electric vehicle ideal for Indian roads, whereas the BMW-i8 and Tesla are rather expensive. The Mahindra E2O is the most popular electric car in India14.The famous Tata Motors, has also unveiled plans to roll out a series of electric vehicles for the Indian car market. Another futuristic idea is a flexible-fuel vehicle that uses a mixture of 
input fuels mixed in one tank - typically gasoline and ethanol, methanol, or biobutanol. It is opined that a hybrid vehicle using alternative fuel for basic functions and BS-VI fuel is the best solution for emission minimization. The shift to electric vehicles will also be a boon to Indian passengers in view of fluctuating crude oil prices.

The Mahindra E20 has the cost advantage of INR 0.45 per kilometer, presuming electricity charges of INR 5.0 per unit and all that the car needs are just 10 units for a full charge. Assume one drives about $12000 \mathrm{~km}$ per year (1000 km per month), one would hardly incur a running cost of INR 5400 per year. On the other hand, for a petrol driven car like Ignis one would cough up INR 38400 per year on fuel. If one considers the cost of running fuel efficient diesel variant of the Ignis, he will still spend INR 25800 on the diesel to cover the same distance. Thus, Evs are not only eco-friendly but result in considerable savings not only for the individual but also for the government in terms of precious foreign exchange. Federation of Automobile dealers Association (FADA) the apex body has filed application with the Supreme Court seeking extension sale and registration of BS-IV vehicles till May 31st ,2020 from 1st April 2020 due to the outbreak of the COVID-19.Further COVID- 19 will also hamper the production of BS-VI diesel vehicles as many automakers in India import about 10 percent of their raw material from China and disruption in availability of these spare parts is likely to hamper the production across all segments including electric vehicles. This offers multiple challenges to both the manufacturers and the government to seek alternatives solution to the problem in future. Adding to the cup of woes the decelerating growth of virus-hit economy may also impact the demand for BS-VI vehicles The government can revive consumer spending by reducing taxes across multiple levels for a temporary period. This may involve reducing registration charges, Goods and Services Tax (GST) as well as cess imposed at the state level. The expansionary fiscal policy can spur the demand in the market and revive the fortunes of auto industry. Similarly, taxes can be reduced on important components such as catalytic converters which are critical for compliance with BS-VI emission norms. Since precious imported raw materials such as palladium and rhodium are used, there is an urgent need to roll back import duty on these items which was increased from $7 \%$ to $15 \%$ in the recent budget. The Novel Cornavirus lockdown might have done a world of good to the environment by improving the air quality and perhaps changed consumers preference for vehicles having low emission levels. This augurs well for BS-VI fuel norms and for companies innovating and introducing ecofriendly vehicles.

\section{REFERENCES}

1. Deepak Singh, Anil Kumar Sarma and Sarbjot Singh Sandhu (2019) 'A comprehensive experimental investigation of green diesel as a fuel for CI engines', International Journal of Green Energy, Vol.16, Iss. 14, pp.1152-1164

2. MaMahzabin Chowdhury, Khan Salam and Richard Tay (2013) 'Consumer preferences and policy implications for the green car market 'Marketing Intelligence \& Planning Bradford, Vol.34, Iss.6, pp 810-827

3. Martin Derrick, Surveys Edition (23 Oct2003) 'Green fuels: Financial incentives for a greater future Today's alternative fuels can be as friendly to the fleet manager's pocket as they are to the environment, ' Financial Times, London (UK)

4. Patel,Harish Kumar, Kumar, Saurabh (2017) 'A Critical Study on Performance of Diesel Engine using mixture of Diesel and Bio- Diesel as a Working Fuel and Influence of Aluminum Oxide Nanoparticle Additive- A Review,' Research Journal of Engineering and Technology,Vol.8,

5. Iss.3, pp 295-298 
6. Wang, Yutao; Hansson, Lars; Sha, Nan; Ding, Yanqiang; Wang, Renqing et al.(2013) 'Strategic assessment of fuel taxation in energy conversation and CO2 reduction for road transportation: a case study from China' Stochastic Environmental Research and Risk Assessment; Heidelberg,Vol.27, Iss.5, pp1231-1238

7. Yakup Kar and Huseyin Deveci (2007) 'Importance of P-Series Fuels for Flexible-Fuel Vehicles (FFVs) and Alternative Fuels' Energy Sources, Part A: Recovery, Utilization, and Environmental Effects, pp909-921 